\title{
Leituras e representações do ano de 1968 no Brasil — algumas anotações
}

Alipio Freire*

Noivas de maio - apenas

um antecedente histórico.

Ou: sua bisavó era a culpada

No Brasil, mães, tias e avós daqueles que em 1968 tinham por volta de 18 anos (ou mais), costumavam casar, como acontecia pelo menos desde o século XIX, no mês de maio. Era o que a Europa - e especialmente a França faziam. Assim, copiavam dos figurinos franceses os modelos dos vestidos de noiva e, das revistas vindas de Paris (a Cidade-Luz que exportava cultura, costura e cosméticos) e de outros centros do Hemisfério Norte, hábitos e costumes que, uma vez incorporados, contribuíam para nos manter atualizados e acomodados na situação de culturalmente colonizados. Para os noivos, a referência era Londres - símbolo da elegância, da masculinidade e da sobriedade, em que pesassem os clubes privados de cavalheiros.

Obviamente, essa condição de culturalmente dominados não era um objetivo em si mesmo, mas um meio - como até hoje acontece - de absorver a produção e os valores dos países centrais do capitalismo. Assim, os casamentos das faixas mais abastadas dinamizavam — além da indústria inglesa de louças e de outros serviços de casa - a produção das tecelagens e das indústrias francesas de confecçôes e acessórios, consumindo suas sedas e rendas, lingerie, enxoval de cama-banho-e-mesa e outras manufaturas de tecidos e petrechos como luvas, bolsas de festas, sapatos e todo um arsenal de perfumaria - dos extratos aos sais de banho, sabonetes, etc., produtos daquela estação, para não falarmos dos vinhos e outras bebidas, ou das mercadorias importadas pelos grandes atacadistas de Marselha (ou Liverpool), que as redistribuíam para o resto do mundo. Além, é claro, de colaborar para reproduzir de forma ampliada e manter um determinado tipo de estrutura familiar, em nosso caso claramente patriarcal, suposta, hipócrita e teatralmente, monogâmica e monândrica.

* Nascido em Salvador (BA) em 4 de novembro de 1945, vive em São Paulo desde dezembro de | 96 I. É jornalista, escritor e artista plástico. alavermelha@hotmail.com 
O problema, porém, é que as noivas francesas casavam em maio, porque este mês, no Hemisfério Norte, consiste no apogeu da primavera, quando o frio acaba, o degelo já se faz, as plantas florescem, insetos, pássaros e demais animais acasalam-se, etc., ao mesmo tempo que se anuncia o verão - boa temporada para férias e viagens. Este não era (e por enquanto, apesar das mudanças climáticas, continua não sendo) o caso do Hemisfério Sul, que em maio vive seu outono e as vésperas do inverno - detalhes áridos e absolutamente sem qualquer sentido para as nossas noivas de maio e seus partners de altar e tabelião. O importante era casar como e quando se fazia em Paris, incluindo, sempre que possível, uma lua-de-mel na capital das luzes, com direito a missa e comunhão na catedral de Notre Dame, além de uma noite na Ópera, uma visita ao Louvre e uma foto na Torre Eiffel.

Sem dúvida, como expressamos acima, a possibilidade desses ritos de passagem completos constituía-se em um direito (absolutamente não isonômico e, portanto, privilégio) das elites. Apesar disso, como valor, como referência, era algo que cortava transversalmente e se fazia dominante no conjunto da sociedade.

Os anos passaram-se, e o mito "maio - o mês das noivas", se não foi de todo abandonado, pelo menos perdeu muito do seu espaço, seja graças à reordenação do capital em termos internacionais e à emergência de novas potências econômicas e políticas, seja por influência de valores e práticas postos coletivamente em ação a partir de 1968 . Ou, mais provavelmente, pela interação desses dois fatores e outros mais.

Brasil, maio de 68. Ou: da insubordinação, a um novo parâmetro de subordinação

O fato é que, tempo-vai-tempo-vem, as "noivas de maio" acabaram cedendo sua primazia no calendário das subordinações culturais às Luzes, ao "Maio de 68".

Explicamos: embora, em nosso país, os grandes e mais importantes acontecimentos de 1968 tenham ocorrido a partir do final de junho e, sobretudo, no último trimestre daquele ano, grandes editoras, a grande mídia comercial, muitas academias e outras instituições responsáveis pela reprodução ampliada da ideologia dominante insistem em comemorar (por intenção e/ou ignorância), no Brasil, o "Maio de 1968".

É outra vez Paris nas paradas.

Para nos determos apenas em dois episódios: na França, após uma noite de barricadas, no dia 11 de maio de 1968, 800 mil estudantes e operários saíram em passeata pelo Boulevard Saint-Michel (Paris) e, no dia 20, uma greve geral 
de 20 milhões de trabalhadores (a maior do Ocidente, pelo menos no pós1945), aliada a uma greve geral estudantil, parou o país, obrigando o presidente, general Charles De Gaulle, a retirar-se para a Bélgica.

No Brasil, as manifestaçôes nesse mês foram absolutamente mais modestas. $\mathrm{O}$ episódio mais marcante aconteceria no $1^{\circ}$ de maio, quando uns poucos milhares de trabalhadores de S. Paulo (a maioria dos quais ligados a oposiçóes sindicais) apedrejaram o governador Abreu Sodré, seus secretários de Justiça, Trabalho e Interior, o Chefe da Casa Militar e demais autoridades que faziam uma comemoração oficial do Dia Internacional do Trabalhador, na Praça da Sé. O governador e sua corte abandonaram em fuga o palanque, tomado de assalto pelos manifestantes que, em seguida, colocaram fogo e saíram em passeata de protesto contra a ditadura. A passeata seguiu até a Praça da República. No cruzamento das avenidas São João e Ipiranga, militantes, improvisando um aríete com um caibro, investiram contra o Citibank e quebraram seus vidros.

Naquele dia $1^{\circ}$, houve também conflitos na rua, prisōes e feridos em Belo Horizonte, quando a PM reprimiu com violência a tentativa de transformar o comício em passeata.

Ao longo do mês, foram registradas algumas escaramuças estudantis, as mais intensas das quais em Belo Horizonte (MG), mas nada que se possa comparar ao que já se manifestara antes, a partir do assassinato do estudante Edson Luiz, no restaurante Calabouço, no Rio (28 de março). Menos ainda ao que se desenrolaria a partir do mês seguinte, com a Sexta-Feira Sangrenta (21 de junho), quando as forças policiais militares reprimiram violentamente os estudantes cariocas, provocando diversas mortes (alguns jornais chegaram a falar em 27 manifestantes e um policial mortos), cujo desdobramento foi a "Passeata dos Cem Mil”, no dia 26 de junho.

No Brasil, nem mesmo episódios mais "frugais", como a eleição da brasileira Martha Vasconcellos, Miss Universo, aconteceriam em maio, mas dois meses depois (13 de julho).

Seria risível a tentativa de comparação com os acontecimentos do mês de maio na França (ou mesmo em outros países do Hemisfério Norte, como Estados Unidos, Itália e Alemanha, ou ainda com o que acontecia no Vietnã e em todo o Sudeste Asiático), caso não o estivéssemos fazendo apenas para realçar o grotesco dessa nova "noiva-de-maio". Ora, comparar o governador Roberto de Abreu Sodré ao presidente Charles De Gaulle é por si só um disparate, não importando o grau de afinidade que se possa eventualmente ter com qualquer dos personagens.

Enfim, como diria o cronista social carioca Zózimo, "pior que um novo rico, somente um novíssimo rico", ao que acrescentaria pressuroso seu colega Ibrahim Sued: "Também, o que seria da vida sem o supérfulo?" (sic). 
No quadro (cronologia) que publicamos (ver pág. 259), selecionamos uns poucos acontecimentos que tiveram lugar no Brasil e que consideramos os mais significativos daquele ano. Ali, percebe-se claramente que, em nosso país, a "crise-68" manifestar-se-ia e aprofundar-se-ia a partir de outubro, chegando ao seu ponto mais agudo no dia 13 de dezembro, com a decretação do Ato Institucional número cinco - o AI-5.

\section{Tomando a invasão do \\ Crusp como objeto \\ de análise e de reflexão}

Poucos dias depois da decretação do AI-5, entre outras medidas do regime, forças da repressão invadiram o Conjunto Residencial da Universidade de São Paulo - Crusp, onde se alojavam estudantes universitários (homens e mulheres) daquela instituição. Desde o primeiro semestre daquele ano, o bloco G do Conjunto Residencial havia sido ocupado por estudantes - a construção do bloco havia sido concluída em janeiro ou fevereiro, mas o preço para ali morar era inacessível aos jovens, e a nova unidade havia permanecido vazia até ser tomada pelos estudantes.

Os residentes no Crusp não eram, em sua totalidade, militantes e, menos ainda, engajados em organizações políticas clandestinas. Sem dúvida, porém, em sua mais absoluta maioria colocavam-se numa atitude crítica com relação ao regime, ao qual se opunham por diversos e nuançados vieses, que implicavam diferentes temas e motivações e, até mesmo, "graus": isto é, muitos (quem sabe, a maioria) não apenas buscavam colocar em xeque o regime, mas o próprio sistema. Ou seja, para esses, não se tratava apenas de pôr fim à ditadura, mas também de destruir o próprio capitalismo, substituindo-o pelo socialismo ou por outro sistema de talhe popular. Para outros, o choque colocava-se muito mais no plano das liberdades individuais.

Era no salão do Centro de Convivência (situado no bloco G do Conjunto Residencial) onde aconteciam as grandes assembléias do movimento estudantil de São Paulo, animadas pelos grêmios e centros acadêmicos da USP, além da União Nacional dos Estudantes - UNE - e da União Estadual de Estudantes de São Paulo - UEE-SP. O espaço também abrigava encontros de outras entidades estudantis, inclusive secundaristas.

Ou seja, o Crusp era um importante centro de efervescência, discussão e ação política. Por isso, na madrugada de 18 para 19 de dezembro, foi invadido e saqueado por tropas formadas por efetivos tão jovens quanto os estudantes que ali residiam. 
Do butim recolhido, como era praxe, os repressores certamente guardaram para si uma parte (insignificantes jóias, enfeites, pequenos objetos, roupas, etc.). Outra parte, porém, tinha um destino já reservado pelos comandos: uma grande exposição do "material subversivo apreendido", que organizariam, logo em seguida, no saguão dos Diários Associados (do senhor Assis Chateaubriand — o Chatô) —, na Rua 7 de Abril, no centro da capital paulista.

A presença massiva de jovens em ambos lados dessa trincheira (estudantes e repressores), por si só, já desqualifica uma leitura recorrente, mais ou menos explícita (dependendo do autor), dos eventos de 1968 como resultado de um "choque geracional" - do que trataremos adiante.

Por enquanto, interessa-nos fundamentalmente a grande exposição do material apreendido.

A mostra, no saguão da "Casa de Chatô", como era conhecido o local pelos jornalistas, foi inaugurada com pompa e circunstância e foi objeto de cobertura pela grande mídia de então, com direito a entradas (inserts) nas televisões a todo momento, como pequenos editoriais de propaganda, enquanto durou a exposição, do mesmo modo e no mesmo estilo da campanha do "Dê ouro para o bem do Brasil", que teve lugar naquele mesmo hall logo depois do golpe de 1964. Os telejornalistas Tico-Tico e Maurício Loureiro Gama - que já haviam coberto campanhas anteriores desse mesmo estilo - viveriam ali novos dias de glória, com suas entradas no ar a cada 20 minutos ou meia hora, ao vivo, construindo a histeria dos telespectadores contra os "subversivos", os "comunistas", "os sabotadores dos lares" e uma postura incondicional de apoio à "Revolução Democrática Redentora" (leia-se o golpe de 31 de março).

\section{O que mostrava e como}

se organizava a exposição

Mas o que iriam expor de tão significativo e aterrorizador, e como iriam organizar essa mostra?

O material apreendido foi classificado em três grandes blocos, expostos amontoadamente na seguinte seqüência: armas; literatura; e subversão da moral e dos bons costumes.

Ora, se algum estudante tivesse alguma arma de fato em seu apartamento ou se outros tivessem documentos comprometedores (geralmente textos de organizações clandestinas ou livros marxistas e assemelhados), o que era mais que provável é que já se houvessem desfeito das primeiras e destruído ou removido para outros locais os segundos, pelo menos desde o 13 de dezembro. 
De todo modo, a exposição se fez, sob a responsabilidade de um curador certamente recrutado nos mais baixos escalóes da Polícia - ou quem sabe, pelo próprio coronel Jarbas Passarinho, um dos intelectuais do regime.

No setor das armas, expunham-se algumas centenas de facas domésticas, canivetes e estiletes, além de pouco mais de meia dúzia (literalmente) de garruchas de bucaneiros, peças geralmente do século XIX, de um ou dois tiros, objetos muito usados então para a decoração de ambientes, uma vez que sua serventia para qualquer combate era nula, e munição já não mais se fabricava. Ornamentando tudo isso, em posição de destaque e bem visíveis, três ou quatro pistolas automáticas, meia dúzia de revólveres calibre 32 e 38 e talvez duas ou três winchesters (ou assemelhadas) com cara de coisa que foi agregada, de última hora, e constituindo-se na cereja-do-bolo daquela coleção de inutilidades militares.

No segundo setor, exibia-se a "farta literatura" subversiva. Na ausência de significativo volume de documentos clandestinos mimeografados ou de obras de Marx, Engels, Lênin, Guevara, Mao, Ho Chi Minh, Clausewitz, ou etc. (comuns nas prateleiras de qualquer estudante engajado de então), tomavam seus lugares mal-ajambradas pilhas de livros, coroadas por títulos como $O$ vermelho e o negro, de Stendhal (1783-1842), Manual de bombas hidráulicas, além de outras pérolas do gênero. Revistas estrangeiras, como Les Temps Modernes, New Left, ou mesmo Cahiers de Cinéma faziam boa vista, dado o mistério do que ali estava escrito para a maioria, e como provas incontestes da "conspiração com potências estrangeiras" - leituras induzidas ou explicitamente propostas pelos inserts em TVs e rádios.

Por fim, no terceiro setor, a investida dos "subversivos/as" contra "as mais sagradas tradiçỗes cristãs do nosso povo" e pela "destruição da família". Ou seja, amontoados de caixas de pílulas anticoncepcionais e preservativos, a sinalizar a "devassidão" e "promiscuidade" que reinavam nos alojamentos invadidos, onde "moças tinham experiências sexuais pré-matrimoniais", que sem dúvida alguma transgrediam "os limites do amplexo mútuo", aliciadas e orientadas por "cripto-comunistas financiados pelo ouro de Moscou" (ou também Havana e Pequim), conforme rezava o jargão da Guerra Fria.

Ou, como já glosara Tom Zé, em sua "São São Paulo, meu amor", poucos meses antes:

[...] Salvai-nos por caridade/ pecadoras invadiram/ todo o Centro da cidade/ armadas de ruge e batom/ dando vivas ao bom humor/ num atentado contra o pudor/ A família protegida/ O palavrão reprimido/ Um pregador que condena/ Uma bomba por quinzena /[...]" 
Naquele saguão, a síntese do

que pensavam os senhores do

regime e sua visão de mundo

Obviamente não nos ativemos na descrição (ainda que breve) desse evento, pelo que possa ter de bizarro. O que pretendemos mostrar é o sentido mais geral do golpe de 1964 e em particular do AI-5, e como tudo isso batia de frente com o chamado ideário de 1968. Naquele saguão estava exposta a síntese do que pensavam os senhores (civis e militares) do regime, sua visão de mundo, e qual a ordem - para além do político (stricto sensu) - que pretendiam para a sociedade. Cada um daqueles setores representava claramente uma esfera onde, depois de destruídas as organizações populares e de trabalhadores logo após o 31 de março e sufocadas e isoladas as experiências operárias de Contagem (MG) e Osasco (SP), pretendiam continuar intervindo prioritariamente e com maior dureza depois do AI-5.

Ou seja, na exposição, os inimigos principais estavam bem claros e hierarquizados:

No primeiro setor e antes de tudo, estavam representadas (ainda que não apenas) as organizações da chamada luta armada (quase todas de matriz marxista), que haviam intensificado suas ações nos centros urbanos naquele ano, depois de ter sido experimentada a tentativa da guerrilha rural de Caparaó (1966-1967), de viés dominantemente nacionalista e logo esmagada, e outras iniciativas ainda anteriores de ações da chamada guerrilha urbana, levadas a cabo no Rio Grande do Sul, já em 1965, pelo grupo ligado a Jefferson Cardim.

No segundo bloco, o saber, o estudo, o pensamento, a inteligência, a capacidade crítica de desejar, querer e propor um outro mundo, um outro sistema ou, pelo menos, um outro regime. Enfim, a liberdade de pensamento e sua manifestação. Mas, como cunhou Millôr Fernandes naqueles (e para aqueles) dias, "Livre pensar é só pensar".

Por fim, o terceiro universo dizia claramente da conservação dos costumes, da condição da mulher na sociedade, "da tradição democrática, ocidental e cristã", etc. E não podia ser diferente: o golpe foi dado com a mobilização, entre outras, da Liga das Senhoras Católicas; da Tradição Família e Propriedade - TFP —; da Marcha da Família com Deus pela Liberdade e de luminares da alta hierarquia da Igreja Católica, do padrão do bispo de Diamantina, dom Geraldo Sigaud, que, em entrevista em Roma (1970), diante de perguntas sobre denúncias de torturas, saiu-se com a célebre frase: "confissões não se conseguem com bombons".

O fato é que essa mostra não apenas dizia dos principais alvos a serem destruídos a partir daquele momento como, sobretudo, deixava transparente 
- pelo material exposto e pela forma como estava exposto - o grau de elaboração e o patamar de sofisticação de onde partiam os senhores do poder para definir e combater seus inimigos. Assim, tematizavam sem rebuços, como atribuição sua, a disputa (pelas armas e por todo tipo de violência própria do Terror de Estado) da política, das armas, do pensamento e dos costumes, cuja normatização tentariam aprofundar. Ao fazer isso, transformaram todas essas questôes em questôes de Estado, de disputa de poder. Desse modo, o que já deixavam claro e propunham os golpistas já antes do 31 de março, agora se aguçava.

Ora, se é verdade que, naqueles tempos de Guerra Fria, todas as questóes tendiam rapidamente a se "politizar" e a assumir extremados contornos ideológicos, no Brasil, a ditadura acentuou ainda mais essa tendência, levando-a ao paroxismo e, portanto, ao estágio da morbidez: era igualmente suspeito e acusado de subversão o militante político clandestino; o que tentasse organizar os trabalhadores e o povo; o pensador/escritor/artista que fugisse às normas do establishment; o jovem de roupas "estranhas" e/ou cabeludo; a jovem que pregasse e/ou exercesse livremente sua sexualidade antes do casamento, etc., ainda que as conseqüências, de modo geral, costumassem ser bastante diferentes de um para outro caso.

Com isso, o que queremos dizer é que não podemos falar de nenhum aspecto da vida daqueles anos, num Brasil onde, aos olhos do poder, a microssaia era quase tão perigosa quanto o porte de uma arma, sem tratarmos diretamente da questão da ditadura, da política, da disputa de poder. Se, numa democracia (por mais limitada que seja), costumam ser muitas as mediações e as variáveis entre o comportamento cotidiano dos cidadãos e o poder do Estado, naquele contexto do regime pós-golpe, tais mediações e variáveis tendiam a zero, mesmo dizendo respeito a manifestaçôes de distintas esferas e matrizes. Isso se coloca ainda com mais intensidade para os acontecimentos ditos de 1968 (que em nosso país já amadureciam desde a década de 1950), quando todas essas esferas estavam fortemente radicalizadas em suas manifestações.

Ou seja, em nosso país, discutir qualquer dos assuntos postos em pauta por 1968, é discutir também o regime e, muitas vezes, o próprio sistema. E é também, mesmo a posteriori, tomar partido.

Jovens estudantes da "classe média"

em ação... ou um bando de jovens "pequenos burgueses" radicalizados

Um problema grave corta transversalmente as diversas representações que são feitas daqueles anos, especialmente 1968. Ele está disseminado, seja em 
trabalhos ficcionais, seja em textos acadêmicos, ou mesmo em textos políticos de esquerda que acabam coincidindo com leituras e versões oficiais da direita, ou ainda com as perigosas reflexôes dos extremistas radicais de centro, que assolam o mundo com o seu "bom senso" de encomenda - ou seja, um senso comum adornado por um palavrório "científico-filosófico".

No caso, as leituras e as versões oficiais da direita têm a intenção e o objetivo muito claros de desqualificar politicamente a história daquele período, fazendo com que aquelas manifestaçôes/erupções não sejam apropriadas como parte da saga do povo brasileiro, questão que se agrava quando muitos estudiosos e artistas (das várias áreas), mesmo sem perceber, fazem eco e legitimam esse tipo de construção.

Trata-se da questão de classe dos protagonistas dos anos 1960, em que se mesclam diversos "mal-entendidos". O discurso hegemônico corrente afirmanos que aqueles protagonistas eram, em sua maioria esmagadora - se não na sua totalidade - "jovens estudantes da classe média".

Em vez de tomarmos essa afirmação como dada, provada e consagrada, detenhamo-nos na sua análise.

"Classe média" é uma expressão impressionista que, na melhor das hipóteses, pode nos falar de determinadas faixas de renda, estabelecidas arbitrariamente a partir dos objetivos (geralmente mercadológicos, mesmo que "mercado de votos"), dos interesses e das intenções do autor que dela se utilize. Afirmar que aqueles sujeitos históricos pertenciam à "classe média" nada nos diz. Exceto se tal expressão vier carregada de um juízo de valor pejorativo (estigmatizante) e/ou se for tratada como sinônimo de "pequena burguesia". Nesse caso, trata-se de um equívoco imperdoável, uma vez que este último conceito, que tem outra matriz de pensamento, é bem preciso e nos diz de relação de propriedade; nos diz do pequeno proprietário de algum negócio que explora a mão-de-obra de um pequeno contingente de trabalhadores (assalariados), apropriando-se, portanto, de parte da mais-valia por estes produzida.

Ora, essa não era a condição de classe da maioria esmagadora dos protagonistas daquelas lutas que, na verdade, eram filhos de assalariados dos mais diversos setores e dos chamados profissionais liberais. E não esqueçamos que os próprios profissionais liberais naquele momento, pelo menos no Brasil, estavam em processo de franca proletarização - resultado da acelerada monopolização (e mesmo oligopolização) da nossa economia. Ou seja, profissões que tradicionalmente eram exercidas na esfera da iniciativa privada através de pequenos escritórios, consultórios, etc. (como médicos, engenheiros, advogados, dentistas, contadores, etc.), começavam a deixar de existir como tais, passando a ser desenvolvidas fundamentalmente por assalariados dos grandes grupos privados de saúde, engenharia, etc. Se é verdade que em centros menores essa 
proletarização acontecia de modo mais lento, nos grandes centros ela já havia começado cerca de década antes e acelerou-se nos anos da ditadura.

Mais que isso, a grande maioria (a maioria esmagadora) dos sujeitos dos acontecimentos daqueles anos (e nos referimos aqui, também, aos estudantes) trabalhavam, eram assalariados. Não perceber isso é não conseguir perceber quem eram os protagonistas daquele período histórico, as bases materiais de suas condiçôes de classe, suas necessidades objetivas (incluídas aqui suas subjetividades), seus anseios, seus pensamentos e suas propostas de mudanças.

Como já vimos acima, invocar a questão "choque geracional" para os eventos daquele período é absolutamente descabido. É colocar a contradição principal fora do seu lugar. Existiam jovens dos dois lados das trincheiras: eram jovens os moradores do Crusp, como jovens eram os que compunham as tropas que invadiram aquele conjunto residencial. Aliás, nos anos subseqüentes, à exceção dos comandantes, dos delegados e dos altos escalóes e do oficialato, os torturadores - os que punham a mão na massa - eram tão jovens quanto os torturados.

Aliás, apenas para avivar algumas memórias, lembramos que os grandes dirigentes da Revolução Burguesa na França (1789) eram todos jovens - bem como os de diversos outros processos revolucionários. E mais: uma vez que completamos os 200 anos da chegada da família real portuguesa ao Brasil, não devemos esquecer a idade de Napoleão I, quando "botou para correr" dona Maria: 37 anos. Quatro anos antes (aos 33 anos), depois de guerrear e anexar vários países, já se havia autocoroado imperador na catedral de Paris.

Poderia tratar-se de uma tolice, de um problema menor, de uma implicância nossa rebater exaustivamente a questão de insistirem na condição de jovens dos protagonistas dos anos 1960, caso tal qualificação não viesse sempre acoplada à expressão "classe média" (que se metamorfoseia em seguida em "pequenos burgueses") e, por fim, à condição de "estudantes", de que tratamos logo a seguir.

Chamamos a atenção para o fato de que essa reflexão que vimos fazendo, guardadas as devidas especificidades locais, serve também para os acontecimentos daquele ano (1968) em outros países, não apenas do nosso continente, como também para os Estados Unidos e a Europa, especialmente para a França, ainda que não sejam esses países, neste momento e neste trabalho, objeto da nossa reflexão.

O que é um estudante e

que "metafísicas" envolve?

Encerrando, vejamos a questão de a maioria esmagadora dos protagonistas daquele período histórico ser formada supostamente de estudantes. 
Antes de tudo, afirmar que alguém é estudante não significa nada, além de dizer que essa pessoa está matriculada em algum estabelecimento de ensino - não implicando necessariamente sequer que tal pessoa freqüente com assiduidade o tal estabelecimento. Ou seja, por si só não nos diz de uma condição de classe e sequer de faixa de renda e, como já vimos, a maioria desses estudantes que se engajaram (nos mais diversos níveis) nas lutas de 1968 e de anos imediatamente anteriores e seguintes vinha de famílias de trabalhadores assalariados, sendo muitos deles igualmente assalariados. Lembramos aqui que vivíamos tempos em que o mercado de trabalho ainda se expandia e que os indivíduos com um mínimo de especialização facilmente eram absorvidos por esse mercado.

Isso, porém, resolve apenas uma parte da questão que pretendemos tratar.

Um segundo aspecto, de grande importância, é entendermos que, graças à política populista em curso até 1964, liderada pelo Partido Trabalhista Brasileiro - PTB - e coadjuvada pelo Partido Comunista Brasileiro - PCB, o golpe conseguiu rapidamente destruir todas as organizaçôes de trabalhadores - especialmente dos operários e camponeses. Estando estes sem sólidas organizações em seus locais de trabalho ou em seus bairros de moradia; aglutinados fundamental ou exclusivamente em torno dos dirigentes/lideranças e das sedes dos seus sindicatos e sedes de outros tipos de organizaçôes; submetidos os sindicatos à aprovação e ao reconhecimento do Ministério do Trabalho e tendo suas finanças geradas a partir do imposto sindical, recolhido pelo Ministério, que o redistribuía para os sindicatos; também atreladas muitas das outras organizaçóes dos trabalhadores e do povo às verbas do Estado para seu funcionamento - isso foi suficiente para que os golpistas ocupassem as sedes dos sindicatos e das associações; cassassem e/ou prendessem; e/ou obrigassem à clandestinidade as lideranças sindicais (e de outros tipos de organizações de massa) mais combativas; e, por fim, fechassem a torneira do imposto sindical e de outras verbas públicas. Estava, assim, desarticulado, em poucos dias, todo o movimento dos operários, dos camponeses e dos demais trabalhadores. Foi isso que criou o isolamento político dos partidos e das organizações de esquerda das chamadas massas, e não o inverso, como costuma nos ser apresentado - que teria sido a política levada a cabo pelas novas organizações surgidas no pós-64 que as isolou das massas. Ainda que as políticas dessas organizações pudessem pecar - e efetivamente pecassem - em muitos pontos (e às vezes gravemente), não se deveu a tais organizações o "isolamento das massas"; nem elas o pretenderam, embora, como conjunto, até meados dos anos 1970 não tenham conseguido elaborar estratégias e táticas capazes de superar essa situação (digase de passagem, com raríssimas exceçôes, a maioria foi destruída antes de lograr esse sucesso). 
Assim, no quadro de destruição das organizaçōes operárias, camponesas e de trabalhadores em geral do pós-1964 e de conseqüente isolamento da esquerda, seriam o movimento estudantil e outros setores urbanos os primeiros a reorganizar e constituir alguma força capaz de manifestar seu repúdio ao novo regime. Esses outros setores a que nos referimos, inseriam-se, sobretudo, no universo mais geral dos chamados "trabalhadores intelectuais", como jornalistas, escritores, diretores, atores e outros profissionais de teatro e cinema, escritores, músicos e compositores, alguns setores do professorado (sobretudo, mas não apenas, universitário), diversas categorias de trabalhadores do chamado setor de serviços, etc. Uma consequiência disso foi que as organizaçôes políticas de cunho partidário e de ação clandestina, surgidas depois do golpe, cresceriam, nesse momento, fundamentalmente nesses setores, uma vez que o recrutamento de quadros e militantes se deu no interior dos movimentos, e não fora deles.

$\mathrm{Ou}$ seja, do nosso ponto de vista, o mais correto seria entendermos que esses sujeitos (que não foram os únicos, ainda que possam ter sido a maioria e ter ganhado visibilidade naquele momento) não eram "jovens-estudantes-daclasse-média”, como pretende o cacoete (pois que não se trata de estudo sério), mas jovens trabalhadores, cuja grande maioria ainda estudava; outros eram profissionais do chamado setor de "trabalhadores intelectuais" e dos serviços.

\section{Os militares nacionalistas e}

de esquerda, a classe operária, e a intensificação da "luta armada"

Mas nem só de movimento estudantil e de "trabalhadores intelectuais" viveram aqueles anos, em especial 1968.

Primeiro, trataremos de outro equívoco, que tem subjazido a muitas das representaçóes do período. Ao classificar o golpe de 64 como um "golpe militar" e o regime que implantou, como uma "ditadura militar", costuma-se obliterar o conteúdo de classe de ambos, ao mesmo tempo que se lhes confere (ao golpe e ao regime que lhe sucedeu) um caráter estamental e/ou corporativo. Isso tem levado a um raciocínio binário e maniqueísta. $\mathrm{Na}$ verdade, tratou-se de um golpe da grande burguesia brasileira subsidiária do grande capital internacional; das grandes empresas internacionais (sobretudo estadunidenses) que aqui operavam (daí a importância e a imprescindibilidade de articulação com o governo e as empresas de Washington); do latifúndio; dos banqueiros; da "direita ideológica”; da grande maioria da então mais alta cúpula da Igreja Católica (Estado do Vaticano), que tiveram como braço armado as forças armadas, cuja cúpula (em sua maioria esmagadora) participou de toda a conspiração, garantindo em seguida o novo regime. 
O golpe foi dado, por esse conjunto de classes e setores, contra um programa de reformas de interesse popular, das quais se beneficiariam setores do capital nacional, a classe trabalhadora e o povo.

Ora, se - como já afirmamos um pouco antes - "discutir qualquer dos assuntos postos em pauta por 1968 é discutir também o regime e, muitas vezes, o próprio sistema", é fundamental que se entenda o que se passava de fato. Ou seja: impossível discutir aqueles anos - e 1968 - no Brasil, sem entender o que acontecia na política (política = luta de classes), mesmo que a política no sentido restrito não seja o objeto central da representação que se queira construir.

Com o golpe civil-militar de 1964, milhares de militares foram expulsos, cassados e/ou submetidos a inquéritos policiais militares (os famigerados IPMs). Sobretudo na Marinha e no Exército, os processos de indenização de militares punidos no pós-64, na Comissão de Anistia do Ministério da Justiça, somaram 15 mil. Desses milhares, depois de afastados das Forças Armadas, nem todos foram para casa e arranjaram outra profissão. Muitos se organizaram e prosseguiram em sua militância. Eram geralmente nacionalistas, engajados nas reformas do Governo João Goulart, e outro tanto, socialistas de diferentes matizes.

Não por acaso, uma das primeiras manifestaçôes de enfrentamento armado do regime (a primeira de maior envergadura) foi o episódio conhecido como a Guerrilha de Caparaó (1966-1967), animada e organizada por setores nacionalistas, cujo contingente de participantes era formado quase totalmente por militantes com origem no Exército e na Marinha, conforme já citamos acima.

Caparaó aconteceu e foi derrotada às vésperas de 68. Às portas de 68 .

Outros dissidentes das forças armadas iriam engajar-se em diversas das novas organizaçóes de esquerda que surgiram naqueles anos e que, mesmo na clandestinidade, articulavam-se com as manifestaçôes então em curso. Além disso, havia também militares ligados ao PCB.

Por outro lado, durante os anos pós-golpe e em 1968, diversas organizações operárias prosseguiram seus trabalhos, enquanto outras foram criadas. No primeiro caso, temos, apenas como um exemplo, a Frente Nacional do Trabalho - organizada por católicos de esquerda. No segundo, temos as oposições sindicais - que se articularam por todo o Brasil, sendo a mais conhecida a oposição sindical metalúrgica de São Paulo - animadas por marxistas e por cristãos de esquerda. Ou seja, a classe operária (e outros trabalhadores assalariados), depois das intervenções dos governos pós-golpe, também se reorganizava.

E foi nesse movimento que eclodiram, em 1968, as greves de Contagem (MG) e de Osasco (SP). Se a primeira alcançou conquistas, apesar das ameaças e das intervençôes do coronel-ministro do Trabalho Jarbas Passarinho, de posse da experiência dessa, a de Osasco foi imediatamente sufocada pelo regime. O 
fato é que essas greves também dariam importantes quadros para as organizações políticas clandestinas, armadas ou não.

\section{Alguma conclusão}

A partir das questôes acima levantadas, que contestam uma certa leitura sobre o ano de 1968 em nosso país, contrapomos versão distinta para aqueles acontecimentos.

1. Falar em "Maio de 68" em nosso país (ou comemorar essa data) é, na melhor das hipóteses, uma tolice da mesma envergadura que o "ideal" das noivas de maio. Não atende à realidade dos fatos. $\mathrm{Na}$ verdade, os meses mais importantes e intensos, em nosso país, correspondem ao último trimestre daquele ano.

2. Diferentemente do que se costuma repetir, são múltiplos os protagonistas dos anos 1960 (especialmente de 1968) no Brasil, e reduzi-los a "jovens estudantes de classe média" ou "jovens estudantes da pequena burguesia", além de não corresponder à realidade (objetividade factual), tem, por isso mesmo, conduzido a uma série de conclusões equivocadas; à construção de personagens de ficção postiços; e a um não-entendimento adequado daquele tempo e de seus protagonistas. Além de tudo, essa caricaturização e essa estigmatização desses protagonistas têm servido à construção de uma história oficial pela direita que, enxergando aqueles episódios como uma "estudantada", excluiu os levantes daqueles anos da saga do povo brasileiro, em busca de uma nova sociedade fundada na igualdade e liberdade.

3. Entender o regime implantado no pós-64 como uma "ditadura militar" é esconder seu caráter de classe e não perceber que o golpe resultou da disputa e do choque entre dois projetos de país: um, em curso antes do 31 de março, que propunha um desenvolvimento nacional fundado na distribuição de riquezas e numa política internacional independente e que foi derrotado. $\mathrm{O}$ outro - o programa dos golpistas - que pressupunha um desenvolvimento nacional fundado na concentração de riquezas e numa política internacional subordinada aos interesses econômicos do grande capital internacional e atrelada politicamente aos desígnios dos EUA.

4. Os acontecimentos, no Brasil, que dão corpo ao que se chama "movimento de 68 ", ou simplesmente "68" só podem ser entendidos se pensados no contexto específico da ditadura civil-militar aqui vigente, bem como da desorganização das forças populares resultantes do populismo que dominou a política até o 31 de março.

5. A não-observância dessas questões que aqui levantamos (ou pelo menos das polêmicas que elas suscitam) implicará, sempre, que a maioria das repre- 
sentações e das leituras (ficcionais ou não, e nas mais diversas linguagens) dessa época - exceto algumas poucas memórias de militantes —, ao partir de uma leitura oficial, martelada pela grande mídia comercial e legitimada por alguns trabalhos acadêmicos acabe por centrar seus personagens numa vaga "classe média", sobre um fundo político absolutamente distorcido, em que a classe trabalhadora e o povo ficam eclipsados pela expressão estigmatizante de "classe média”, com raríssimas e geralmente breves alusōes aos personagens oriundos dos demais setores que não os "trabalhadores intelectuais"; além, é claro, dos "jovens estudantes pequeno-burgueses". ${ }^{1}$

Cronologia resumida de alguns dos principais acontecimentos de 1968 no Brasil, construída para ilustrar este texto²

Janeiro e fevereiro

Meses de verão, férias e carnaval no Brasil, não registram nada digno de maior destaque.

O único fato noticiado que se articula com os momentosos acontecimentos desse ano, será em 8 de fevereiro, quando têm início as ações armadas urbanas no Brasil referentes a 1968 e quando, segundo pesquisas iniciais, devem ter ocorrido 23 ações desse tipo.

No dia 8 de fevereiro foi levada a cabo, pela Ala Vermelha, a expropriação de uma perua Kombi, do Banco da Lavoura de Minas Gerais, em Mauá (SP), que transportava dinheiro proveniente da Cia. Ultragás. Nesta ação foram expropriados aproximadamente $\mathrm{NCr} \$ 23.280,00$, equivalentes a $\mathrm{R} \$ 141.308,43$ (valor em $1^{\circ}$ de abril de 2008).

Além disso, podemos apenas citar o texto do coronel do Exército, Meira Matos, publicado em 14 de fevereiro, em que propõe o fechamento do refeitório estudantil Calabouço, no Rio, que classifica de "um foco de agitação". Registro cuja importância reside em suas conseqüências: mês e meio depois, em 28 de março, a polícia invade o local e assassina o estudante secundarista Edson Luís de Lima Souto.

1. Parte deste texto foi resumidamente publicada sob o título "Observações a respeito das leituras sobre 1968", na Revista Teoria \& Debate, Edição Especial - ano 21 , maio de 2008, Fundação Perseu Abramo.

2. Esta cronologia foi realizada a partir de dados pesquisados por: Danilo Cerqueira César, Francielle Jordânia, Gustavo Moura Cavalcanti Mello e Leandro de Oliveira Armelin (em São Paulo); e Lucrécia Batista e Pedro Henrique Nunes (no Rio de Janeiro). 
Março

20 de março

Bomba explode no Consulado dos Estados Unidos em São Paulo. A ação é realizada por um Comando da Ação Libertadora Nacional - ALN.

28 de março

O estudante paraense Edson Luís de Lima Souto, de 19 anos, é assassinado pela polícia no restaurante Calabouço, no Rio de Janeiro, Brasil. Secundarista e pobre, Edson está almoçando no restaurante quando é mortalmente baleado. Ao contrário do que o governo publicou na época, Edson não era líder estudantil nem participava de confrontos armados.

Abril

$1^{\circ}$ de abril

A diretoria clandestina da UNE decreta greve geral (quatro anos do golpe). Manifestações estudantis são reprimidas em várias cidades. Choques estudantes-PM. Morrem os estudantes João Agripino de Paula, no Rio de Janeiro, e Ivo Vieira, em Goiânia. O Exército ocupa o Centro do Rio.

4 de abril

Portaria 177: Costa e Silva proíbe a Frente Ampla.

4 de abril

PMs atacam missa de sétimo dia de Édson Luís. Cavalarianos sobem a escada da Candelária, Rio; 600 prisões.

14 de abril

15 mil metalúrgicos de Contagem (MG) fazem greve e conquistam aumento de $10 \%$, fato inédito desde 1964 .

17 de abril

No Brasil, 68 municípios passam a ser considerados áreas de segurança nacional, extinguindo-se, portanto, as eleições para prefeito nessas cidades.

20 de abril

Atentado a bomba da direita destrói a entrada do edifício do jornal $O$ Estado de São Paulo. A bomba foi colocada por um grupo de direita liderado por um sujeito chamado Sábato Dynotos. Durante muito tempo, o atentado foi atribuído à esquerda. De acordo com levantamentos iniciais, durante 1968 foram realizados pelo menos oito atentados (alguns dos quais a bomba) pela extrema-direita.

26 de abril

Comando da Vanguarda Popular Revolucionária — VPR — explode carrobomba no quartel do $2^{\circ}$ Exército, em São Paulo. 


\section{Maio}

$1^{\circ}$ de maio

Trabalhadores de S. Paulo jogam pedras no governador Abreu Sodré, tomam o palanque da Praça da Sé, colocam fogo e saem em passeata de protesto contra a ditadura. A passeata segue até a Praça da República. Ao cruzar a São João com a Ipiranga, militantes, improvisando um aríete com um caibro, investem contra os vidros do Citibank, que quebram.

25 de maio

O médico Euryclides Zerbini realiza em João Boiadeiro o primeiro transplante cardíaco da América Latina.

Junho

5 de junho

Criado alguns meses antes, em São Paulo, o Comitê de Artistas, Jornalistas e Intelectuais em Geral contra a Censura e pela Liberdade de Expressão e Manifestação inaugura em São Paulo a Feira Paulista de Opinião (mostra de artes plásticas, teatro, cinema e música) que itinerou por diversos teatros, como Ruth Escobar, Arena, Oficina, etc.

21 de junho

Sexta-Feira Sangrenta - Em protesto contra a repressão a estudantes em Belo Horizonte, os estudantes cariocas vão às ruas e sofrem violenta repressão em escaramuças que duram todo o dia e que resultam em diversas mortes (alguns jornais chegam a falar em 27 manifestantes e um policial mortos).

23 de junho

Estudantes da USP ocupam a Faculdade de Filosofia Ciências e Letras, na Rua Maria Antônia. Ao longo do mês e a partir de então, várias outras universidades seriam ocupadas em todo o Brasil. 26 de junho

Passeata dos Cem Mil. Em protesto contra a brutal Sexta-Feira Sangrenta no Rio. Organizada por artistas, intelectuais, jornalistas, por vários sindicatos e associações, pela organização União das Mães, por religiosos e estudantes, a Passeata dos Cem Mil lota a Avenida Rio Branco e todo o centro do Rio de Janeiro.

Protestos são realizados em todo o país.

Junho

Ainda em junho, o grupo de extrema-direita liderado por Sábato Dynotos, em São Paulo (SP), coloca uma bomba na ponte de ferro sobre o rio Tietê (por onde transitavam os trens da Santos-Jundiaí) e faz explodir um carro-bomba em frente ao Dops paulista, quebrando todas as vidraças do prédio. 
Julho

4 de julho

Passeata estudantil de 30 mil no Rio.

5 de julho

Proibidas as manifestações de rua.

Mais de 300 mil estudantes protestam nas principais cidades do país.

17 de julho

Greve em seis metalúrgicas de Osasco, SP, com ocupação da Cobrasma.

O ministro do Trabalho, coronel Jarbas Passarinho, ordena intervenção no Sindicato.

18 de julho

Jornalistas, artistas, intelectuais e estudantes estruturam, em São Paulo, Comitê de Apoio à Greve de Osasco que organiza várias manifestações e outras ações de propaganda e solidariedade aos grevistas. Sufocada a greve dias depois, vários membros do Comitê de Apoio foram detidos ou passaram a ser procurados.

18 de julho

O Comando de Caça aos Comunistas depreda o Teatro Ruth Escobar (São Paulo-SP), onde se apresenta a peça Roda viva, de Chico Buarque, e espanca vários artistas.

20 de julho

Sufocada a greve de Osasco, SP; os metalúrgicos, com as mãos na cabeça, são retirados da Cobrasma por carros blindados e por metralhadoras do Exército.

22 de julho

Atentado a bomba, pela extrema direita, contra a sede da Associação Brasileira de Imprensa - ABI, no Rio de Janeiro.

Julho

Ainda no mês de julho, um comando da Ação Libertadora Nacional toma e expropria trem pagador na linha Santos-Jundiaí.

Agosto

29 de agosto

Forças da Polícia Militar e Polícia Federal invadem a Universidade de Brasília.

\section{Setembro}

2 de setembro

A propósito da invasão da Universidade de Brasília, o jornalista e deputado federal Márcio Moreira Alves (MDB-GB) discursa no Congresso, criticando a 
ditadura, em especial os militares. Em determinado momento, o deputado conclama as jovens moças a que não aceitem dançar com cadetes ou outros militares - o que será considerado posteriormente como um dos pontos altos da afronta contra o regime.

7 de setembro

Em Goiânia, protesto de estudantes impede o desfile militar de 7 Setembro na cidade. Passeata dos Cem Mil, em protesto contra a brutal Sexta-Feira Sangrenta no Rio.

13 de setembro

Os ministros militares taxam de "ofensiva" a fala do deputado Márcio Moreira Alves, proferida no dia 2 de setembro.

14 de setembro

Extrema-direita coloca bomba na livraria Civilização Brasileira.

\section{Outubro}

$1^{\circ}$ de outubro

Denúncia do Caso Parasar: plano de usar essa unidade da Força Aérea Brasileira - FAB para o extermínio de oposicionistas.

2 ou 3 de outubro

A Rua Maria Antônia (São Paulo-SP), onde se situavam a Universidade Mackenzie e a Faculdade de Filosofia, Ciências e Letras da Universidade de São Paulo, é palco do conflito que ficou conhecido como "A Batalha da Maria Antônia”. A PM intervém, o secundarista José Guimarães é morto por um tiro disparado pelo Comando de Caça aos Comunistas - CCC, alojado no alto de um prédio do Mackenzie.

8 de outubro

Dez mil canavieiros entram em greve em Cabo (PE).

8 de outubro

Grupo de direita seqüestra em São Paulo (SP) a atriz Norma Benguel. 12 de outubro

O governo pede à Câmara que casse Márcio Moreira Alves.

12 de outubro

Comando da VPR executa em S. Paulo Charles Chandler, capitão do Exército dos EUA acusado de ser agente da CIA.

12 de outubro

Presos cerca de 740 estudantes que participam do $30^{\circ}$ Congresso da União Nacional dos Estudantes - UNE - , reunido clandestinamente em Ibiúna (SP). A UNE havia sido fechada e colocada na ilegalidade logo em seguida ao golpe de 1964. 
22 de outubro

Dia nacional de protesto contra a prisão dos estudantes no $30^{\circ}$ Congresso da UNE. Passeatas estudantis em várias cidades.

24 de outubro

Extrema-direita metralha, em Recife (PE), a casa de D. Helder Câmara, arcebispo de Recife e Olinda.

\section{Novembro}

O mês de novembro é marcado pela visita da rainha Elizabeth $2^{\text {a }}$ da Inglaterra e seu marido, o príncipe Phillip, ao Brasil. Uma série de medidas repressivas, que vinham sendo anunciadas pelos mais altos escalóes do regime, foi adiada para quando partisse o casal britânico.

A grande mídia comercial, além das atividades pertinentes aos visitantes, como a assinatura de acordos comerciais, a inauguração da Feira da Indústria Britânica e da nova sede do Museu de Arte de São Paulo - Masp —, na Avenida Paulista, e das festas e galas, discutiu durante esse tempo as medidas que seriam tomadas no mês seguinte, depois da partida da chefe de Estado e do seu consorte.

\section{Dezembro}

2 de dezembro

Comando de Caça aos Comunistas coloca bomba no Teatro Opinião, Rio de Janeiro (GB).

13 de dezembro

A Câmara dos Deputados, desafiando a ditadura, rejeita por 216 votos a 141, o pedido de licença para processar o deputado Márcio Moreira Alves. À noite, o Ato Institucional no 5 suprime todo resquício do estado de direito, fecha o Congresso e desencadeia nova onda de cassações.

18 para 19 de dezembro

Invasão do CRUSP - Conjunto Residencial da Universidade de São Paulo. Prisões e apreensão de material encontrado nos apartamentos.

Dias depois, o material apreendido será exposto à visitação pública no saguão dos Diários Associados.

22 de dezembro

Denunciados pelo comentarista e locutor de TV Randal Juliano, Caetano Veloso, Gilberto Gil e outros músicos são presos na Boate Sucata, Rio de Janeiro $(\mathrm{GB})$. 
Pro-Posições, v. 19, n. 3 (57) - set./dez. 2008

30 de dezembro

O Governo publica sua primeira lista de cassações pós-AI-5, encabeçada pelo deputado Márcio Moreira Alves. 